\title{
GDP and Dynamic Intensity and Extensity Parameters - Calculation for the Czech Republic and Germany in the Period 1991 - 2017
}

\author{
Petr WAWROSZ, Jiří MIHOLA, Jana KOTĚŠOVCOVÁ \\ University of Finance and Administration, Prague, Czech Republic \\ $\{6399,22548,6688\}$ @ mail.vsfs.cz
}

\begin{abstract}
The paper introduces so called dynamic intensity and extensity parameters and dynamic parameters of the share of the influence of the labor and capital development on the TIF development. The parameters analyze GDP development whether it is based on qualitative or quantitative factors and how change of labor or capital contributes to change of total input (TIF) factor. It can be used as an alternative method to growth accounting. The parameters are calculated for the Czech and German GDP development for the period 1991 2017. The calculation confirms similarity of the development in both countries.
\end{abstract}

Keywords: GDP Development, Dynamic Intensity Parameter. Dynamic Extensity Parameter, Czech Republic, Germany

\section{$1 \quad$ Materials and methods}

The purpose of the paper is to calculate values of dynamic intensive and extensive parameters and dynamic parameters of the share of the influence of the labor and capital development on the TIF development for the Czech Republic and Germany for the period 1991-2017. The article is organized as follows. This chapter describes all parameters. The second one calculates the value of parameters for the mentioned countries in the given period. The third one discusses some issues connected with parameters. Conclusion summarizes main points.

The topic how specific factors contribute to economic development (growth) belongs to the main economic issues (for details see e. g. Sandamo 2011). Principal contribution was done by Solow (1957) and others (e. g. Kendrick 1961, Denison 1962, Jorgerson and Griliches 1967) in growth accounting equation. The equation looks at the economic growth (change) as contribution of labor growth, capital growth and technological progress (total factor productivity) growth. The basic form of growth accounting equation can be written as:

$$
G(Y)=G(T F P)+\alpha * G(K)+(1-\alpha) * G(L),
$$


where $\alpha$ and $(1-\alpha)$ represents the weights expressing impact of capital and labor. The equation assumes constant returns to scale. It further expects perfect competition - generally situation when factors prices coincide with social marginal product and where the revenues of owners of capital and labor equal product $M P_{K} \cdot K$, respectively $M P_{L}$. $L$. As Barro (1999) notes the growth accounting equation is useful if the determinants of factor growth rates are substantially independent from those that matter for technological change. However, the development of labor and capital is interconnected $\mathrm{n}$ reality. The presence of both factors is essential in the economy. Not even a vending machine can do without live labor, just as a man cannot practically do without at least minimal amenities in the economy. The changes of labor or capital usually also affect value of technological progress.

There were made a lot of attempts how to overcome the shortage of growth accounting (see e. g. Barro 1999 or la Grandville 2016 for details). One of them (Mihola 2007a, Mihola 2007b, Hájek and Mihola 2009, Cyhelský, Mihola and Wawrosz 2012, Mihola and Wawrosz 2013, 2014a, 2014b, 2015) introduces so called dynamic intensity parameter $(i)$ and dynamic extensity parameter $(e)$, respectively the dynamic parameter of the share of the influence of the labor development on the total input factor $(T I F)$ development $(l)$ and the dynamic parameter of the share of the influence of the capital development on the TIF development $(k)$. The dynamic intensity and extensity parameters express how change of intensive factors that is represented by change of TFP and change of extensive factors that is represented by change of TIF contributes to change of GDP $(Y)$. Dynamic parameters of the share of the influence of the labor or capital development on the development of TIF similarly express how change of labor or capital contributes to change of $T I F$.

The logic of dynamic intensity and extensity parameters comes from the basic relationship that sees output as the product of inputs and their efficiency (see e.g. Froeb and Ward, 2015, for details). GDP growth, decline or stagnation may be attributable to a change in only one of these variables, with the other variables unchanged, or both variables having an effect. In that event, the effects may also counteract each other, which may even result in a full compensation of the impact of their changes, if one variable rises and the other falls in such a way that the GDP does not change. A change in TIF is related to a change in the amounts of inputs, i.e. to a quantitative or extensive change, and a change in TFP is related to a qualitative or intensive change.

Mathematically, the parameters come from expressing GDP as the product of TFP and $T I F$.

$$
Y=T F P . T I F
$$

$T I F$ is further expressed in the form of Cobb-Douglas function:

$$
T I F=K^{\alpha} \cdot L^{(1-\alpha)}
$$

Both the equation (2) and equation (3) can be made dynamic:

$$
I(Y)=I(T F P) . I(T I F)
$$




$$
I(T I F)=I(K)^{\alpha} \cdot I(L)^{(1-\alpha) .}
$$

It is worth to mention that basic equation of growth accounting (1) can be derived from equation (4) and (5). First change of $\mathrm{Y}$ is expressed as:

$$
I(Y)=I(T F P) \cdot I(K)^{\alpha} \cdot I(L)^{(1-\alpha)} .
$$

Taking a logarithm of this, it is possible to obtain the following expression after introducing the growth rates

$$
\ln [G(Y)+1]=\ln [G(T F P)+1]+\alpha \cdot \ln [G(K)+1]+(1-\alpha) \cdot \ln [G(L)+1] .
$$

For small growth rates of up to $\pm 5 \%$, the following equation is accurate enough for any variable $\mathrm{A}$

$$
\ln [G(A)+1] \approx G(A)
$$

Using this approximate relationship, we can modify expression (12) into

$$
G(Y)=G(T F P)+\alpha \cdot G(K)+(1-\alpha) \cdot G(L)
$$

It must be emphasized that the equation (9) was derived by using an approximate equation (8), and therefore it applies only approximately. Accurate results can be obtained using direct calculations, which do not rely on relationships between dynamic characteristics.

The dynamic parameters of intensity and extensity comes from relationship:

$$
\ln (I(Y))=\ln (I(T F P))+\ln (I(T I F))
$$

The impact of change of intensive factors (dynamic intensity parameter) on GDP change can be then easily expressed as:

$$
i=\frac{\ln I(T F P)}{|\ln I(T F P)|+|\ln I(T I F)|},
$$

Similarly, the impact of change of extensive factors (dynamic extensity parameter) on GDP change can be then easily expressed as:

$$
e=\frac{\ln I(T I F)}{|\ln I(T F P)|+|\ln I(T I F)|} .
$$

The parameters are designed to be able to describe truthfully all possible situations. Specifically, if a change of any factor contributes to production growth, the relevant parameter should be positive (e.g. if a change of intensive factors contributes to growth, the dynamic parameter of intensity is positive), whereas if it leads to a decline in output, the parameter value is negative. If the given factor remains unchanged, the relevant parameter is equal to zero. The following applies to the sum of absolute values of relevant parameters: 


$$
|i|+|e|=1 .
$$

The detailed characteristics of individual situations with values of parameters are specified in Table 1.

Table 1. Overview of individual types of developments $I(T I F)$ and $I(T F P)$ and values of dynamic parameters of intensity and extensity

\begin{tabular}{|c|c|c|c|c|c|}
\hline & $\begin{array}{c}\text { Change of extensive } \\
\text { factors }(I(T I F))\end{array}$ & $\begin{array}{c}\text { Change of intensive } \\
\text { factors }(I(T F P))\end{array}$ & $\begin{array}{c}\text { Change of } \\
\text { output }(I(Y))\end{array}$ & $\begin{array}{l}\text { Values of } \\
\text { intensity } \\
\text { (i) and } \\
\text { extensity } \\
(e) \\
\end{array}$ & $\begin{array}{c}\text { Type of } \\
\text { development }\end{array}$ \\
\hline 1. & growth, $(I(T I F)>1)$ & $\begin{array}{l}\text { unchanged, }(I(T F P)= \\
\text { 1) }\end{array}$ & $\begin{array}{l}\text { growth, }(I(Y) \\
>1)\end{array}$ & $e=1 ; i=0$ & $\begin{array}{l}\text { pure extensive } \\
\text { growth }\end{array}$ \\
\hline 2. & $\begin{array}{l}\text { unchanged, }(I(T I F)= \\
\text { 1) }\end{array}$ & growth, $(I(T F P)>1)$ & $\begin{array}{l}\text { growth, }(I(Y) \\
>1)\end{array}$ & $e=0 ; i=1$ & $\begin{array}{l}\text { pure intensive } \\
\text { growth }\end{array}$ \\
\hline 3. & $\begin{array}{l}\text { same growth as } \\
\text { intensive ones, }(I(T I F) \\
>1, I(T I F)=I(T F P))\end{array}$ & $\begin{array}{l}\text { same growth as } \\
\text { extensive ones, } \\
(I(T F P)>1, I(T F P)= \\
I(T I F))\end{array}$ & $\begin{array}{l}\text { growth, }(I(Y) \\
>1)\end{array}$ & $\begin{array}{l}e=0.5 ; i= \\
0.5\end{array}$ & $\begin{array}{l}\text { pure intensive- } \\
\text { extensive } \\
\text { growth }\end{array}$ \\
\hline 4. & $\begin{array}{l}\text { faster growth than } \\
\text { intensive ones, }(I(T I F) \\
>1), I(T I F)>I(T F P))\end{array}$ & $\begin{array}{l}\text { slower growth than } \\
\text { extensive ones, } \\
(I(T F P)>1, I(T F P)< \\
I(T I F))\end{array}$ & $\begin{array}{l}\text { growth, }(I(Y) \\
>1)\end{array}$ & $\begin{array}{l}e>0 ; i>0 \\
e>i\end{array}$ & $\begin{array}{l}\text { predominantly } \\
\text { extensive } \\
\text { growth }\end{array}$ \\
\hline 5. & $\begin{array}{l}\text { slower growth than } \\
\text { intensive ones, }(I(T I F) \\
>1), I(T I F)<I(T F P))\end{array}$ & $\begin{array}{l}\text { faster growth than } \\
\text { extensive ones, } \\
(I(T F P)>1, I(T F P)> \\
I(T I F))\end{array}$ & $\begin{array}{l}\text { growth, }(I(Y) \\
>1)\end{array}$ & $\begin{array}{l}e>0 ; i> \\
0 ; i>e\end{array}$ & $\begin{array}{l}\text { predominantly } \\
\text { intensive } \\
\text { growth }\end{array}$ \\
\hline 6. & $\begin{array}{l}\text { is greater than } \\
\text { inverted value of } \\
\text { intensive ones, (I(TIF) } \\
>1) \text {, } \\
I(T I F)>1 / \mathrm{I}(\text { TFP }))\end{array}$ & $\begin{array}{l}\text { is greater than } \\
\text { inverted value of } \\
\text { extensive ones, } \\
(I(T F P)<1 \text {, } \\
I(T F P)>1 / I(T I F))\end{array}$ & $\begin{array}{l}\text { growth, }(I(Y) \\
>1)\end{array}$ & $\begin{array}{l}e>0 ; i< \\
0 ; \\
e>|i|\end{array}$ & $\begin{array}{l}\text { extensive- } \\
\text { intensive } \\
\text { compensatory } \\
\text { growth }\end{array}$ \\
\hline 7. & $\begin{array}{l}\text { is greater than } \\
\text { inverted value of } \\
\text { intensive ones, }(I(T I F) \\
<1) \text {, } \\
I(T I F)>1 /(\text { TFP }))\end{array}$ & $\begin{array}{l}\text { is greater than } \\
\text { inverted value of } \\
\text { extensive ones, } \\
(I(T F P)>1 \text {, } \\
I(T F P)>1 /(\text { TIF }))\end{array}$ & $\begin{array}{l}\text { growth, }(I(Y) \\
>1)\end{array}$ & $\begin{array}{l}e<0 ; i> \\
0 ; \\
i>|e|\end{array}$ & $\begin{array}{l}\text { intensive- } \\
\text { extensive } \\
\text { compensatory } \\
\text { growth }\end{array}$ \\
\hline 8. & $\begin{array}{l}\text { equal to inverted value } \\
\text { of intensive ones, } \\
(I(T I F)>1) \\
I(T I F)=1 / I(T F P))\end{array}$ & $\begin{array}{l}\text { equal to inverted } \\
\text { value of extensive } \\
\text { ones, }(I(T F P)<1, \\
I(T F P)=1 / I(T I F))\end{array}$ & $\begin{array}{l}\text { no change } \\
\text { (stagnation), } \\
(I(Y)=1)\end{array}$ & $\begin{array}{l}e=0.5 ; i= \\
-0.5\end{array}$ & $\begin{array}{l}\text { pure extensive- } \\
\text { intensive } \\
\text { compensation }\end{array}$ \\
\hline 9. & $\begin{array}{l}\text { equal to inverted value } \\
\text { of intensive ones, } \\
(I(T I F)<1) \text {, }\end{array}$ & $\begin{array}{l}\text { equal to inverted } \\
\text { value of extensive } \\
\text { ones, }(I(T F P)>1 \text {, }\end{array}$ & $\begin{array}{l}\text { no change } \\
\text { (stagnation), } \\
(I(Y)=1)\end{array}$ & $\begin{array}{l}e=-0.5 ; i \\
=0.5\end{array}$ & $\begin{array}{l}\text { pure intensive- } \\
\text { extensive } \\
\text { compensation }\end{array}$ \\
\hline
\end{tabular}




$$
I(T I F)=1 / I(T F P)) \quad I(T F P)=1 / I(T I F))
$$

10. is less than inverted value of intensive ones, $(I(T I F)<1)$, is less than inverted decline, $e<0 ; i>\quad$ intensivevalue of extensive ones, $(I(T F P)>1$, $I(T I F)<1 / I(T F P))$ $I(T F P)<1 / I(T I F))$

$$
(I(Y)<1)
$$$$
0 \text {; }
$$

extensive

11. is less than inverted value of intensive ones, $(I(T I F)>1)$, $I(T I F)<1 / I(T F P))$

\section{is less than inverted} value of extensive ones, $(I(T F P)<1$, $I(T F P)<1 / I(T I F))$

$i<|e| \quad \begin{aligned} & \text { compensatory } \\ & \text { decline }\end{aligned}$

decline, $\quad e>0 ; i<\quad$ extensive-
$(I(Y)<1) \quad 0 ; \quad$ intensive

$e<|i|$

compensatory slower decline than

decline,

$e<0 ; i<$ decline

12. faster decline than extensive ones, intensive ones, $(I(T I F)$ $<1), I(T I F)<I(T F P))$

$(I(T F P)<1$, $I(T F P)>I(T I F))$

13. slower decline than faster decline than $(I(Y)<1)$ $0 ;|e|>|i|$ predominantly extensive decline intensive ones, (ITIF ) 1$), I(T I F)>$ extensive ones, $(I(T F P)<1)$, I(TFP))

$I(T F P)<I(T I F))$

14. same decline as intensive ones, (I(TIF) same decline as $<1), I(T I F)=I(T F P))$

extensive ones, $(I(T F P)<1)$, $I(T F P)=I(T I F))$

15. declining, $(I(T I F)<$ 1), unchanged, $(I(T F P)=$ 1) decline, $\quad e<0 ; i<$ predominantly $(I(Y)<1) \quad 0 ;|i|>|e| \quad$ intensive decline decline, $\quad e=-0.5 ; i \quad$ pure intensive$(I(Y)<1) \quad=-0.5 \quad$ extensive decline decline, $\quad e=-1 ; i=\quad$ pure extensive $(I(Y)<1) \quad 0 \quad$ decline

16. unchanged, $(I(T I F)=$ 1)

The dynamic parameters of the share of the influence of the labor or capital development on the development of TIF are derived from the equation:

$$
\left.\ln (I(T I F))=\ln (I(K))^{\alpha}+\ln / I(L)^{(1-\alpha)}\right) .
$$

The dynamic parameter of the share of the influence of the development on the development of TIF equals:

$$
k=\frac{\alpha \cdot \ln I(K)}{\alpha \cdot|\ln I(K)|+(1-\alpha) \cdot|\ln I(L)|} .
$$

The dynamic parameter of the share of the influence of the labor development on the development of $T I F$ equals:

$$
l=\frac{(1-\alpha) \cdot \ln I(L)}{\alpha \cdot|\ln I(K)|+(1-\alpha) \cdot|\ln I(L)|} .
$$

The important issue is how to set the weight $\alpha$ and $1-\alpha$ at the above-mentioned equations. Mihola and Wawrosz (2013, 2014a, 2014b, 2015) give $\alpha$ value 0.5. It can be explained by following arguments: 
- There is no reason why, in the event of the complete compensation of capital growth with a decline in labor or in the case of complete compensation of labor growth with a decline in capital, the relationship between the indexes of labor and capital should be asymmetrical. If $\alpha$ was not equal to 0.5 , it would mean that a certain change in the labour $I(L)$ would always be compensated for by a smaller or always larger change in capital $I(K)$. Here it should be noted that modelling the substitution of labour with capital is almost always accompanied by some positive effect, which however captures the change in total factor productivity $T F P$, and hence is not a problem of substitution. Only if $\alpha=0.5$ we receive in the case of complete compensation the well interpretable values $l=50 \%$ and $\mathrm{k}=-50 \%$ or $l=-$ $50 \%$ and $k=50 \%$. Table 2 shows values of $k$ and $l$ for pure development (when only one factor changes and the second one stagnates or when one factor completely compensates the second one).

- The construction of parameters allows to use same value of parameters both for static situation (when values $\mathrm{K}$ and $\mathrm{L}$ do not change) and dynamic situation (when $\mathrm{K}$ and $\mathrm{L}$ change). The weights 0.5 relate to hyperbolic isoquants that do not intersect horizontal and vertical axis expressing the above-mentioned fact that both labor and capital are interconnected and there is no economy using only one factor.

Table 2. The typology of TIF development

\begin{tabular}{ccc}
\hline Type of development & $\boldsymbol{l}$ & $\boldsymbol{k}$ \\
\hline purely labor growth TIF & 100 & $0 \%$ \\
& $\%$ & 50 \\
balanced labor-capital growth TIF & $\%$ & $\%$ \\
purely capital growth TIF & $0 \%$ & 100 \\
& - & 50 \\
balanced labor-capital compensation & $50 \%$ & $\%$ \\
purely labor decline & - & $0 \%$ \\
& $100 \%$ & - \\
purely extensive-intensive decline & - & $50 \%$ \\
purely capital decline & $0 \%$ & - \\
purely intensive-extensive & $50 \%$ & - \\
compensation & $\%$ & $50 \%$ \\
\hline
\end{tabular}

\section{Results}

The all parameters were calculated for German and Czech GDP development for the period1991-2017. The input data $((G(Y), G(K)$ and $G(L))$ was for both countries taken 
or count from Statistical Annexes to the European Economy from Spring 2017, issued by the European Commission, and from the AMECO database. The data for the year 2017 are preliminary. $\mathrm{G}(\mathrm{Y})$ and $\mathrm{G}(\mathrm{K})$ is expressed in in constant prices of the year 2010. The algorithm for the calculations shown below is the same for both analyzed countries.

1. Using the three initial growth rates, we calculate the average growth rate for the entire period.

2. We calculate the growth rate of capital labour equipment $G(K / L)$ using the equation

$$
G\left(\frac{K}{L}\right)=\frac{G(K)+1}{G(L)+1}-1
$$

3. We calculate the growth rate of the aggregate input factor $G(T I F)$ using the equation

$$
G(T I F)=\sqrt{(G(K)+1) \cdot(G(L)+1)}-1 .
$$

4. We calculate the growth rate of aggregate productivity $G(T I F)$ using the equation

$$
G(T F P)=\frac{G(Y)+1}{G(T I F)+1}-1
$$

5. The dynamic parameters of intensity and extensity and dynamic parameters of the share of the influence of the labor or capital development on the TIF development are calculated according to equations (11), (12), (15), (16).

All input data $(G(Y), G(K), G(L))$ and calculated results $(G(K / L), G(T I F), G(T F P), i$, $e, k, l)$ are summarized in percentage form in Table 3 for Germany and in Table 4 for the Czech Republic.

Table 3. The values of dynamic intensity and extensity parameters and dynamic parameters of the share of the influence of the labor or capital development on the development of $T I F$ for Germany.

\begin{tabular}{ccccccccccc}
\hline year & $\mathbf{G}(\mathbf{Y})$ & $\mathbf{G}(\mathbf{L})$ & $\mathbf{G}(\mathbf{K})$ & $\begin{array}{c}\mathbf{G}(\mathbf{K} / \\
\mathbf{L})\end{array}$ & $\begin{array}{c}\mathbf{G}(\mathbf{T I} \\
\mathbf{F})\end{array}$ & $\mathbf{G}(\mathbf{T F P})$ & $\mathbf{i}$ & $\mathbf{e}$ & $\mathbf{l}$ & $\mathbf{k}$ \\
\hline 1991 & 5.1 & 2.8 & 5.3 & 2.4 & 4.0 & 1.0 & 20 & 80 & 35 & 65 \\
1992 & 1.9 & -1.3 & 4.1 & 5.5 & 1.4 & 0.5 & 28 & 72 & -25 & 75 \\
1993 & -1 & -1.3 & -4.2 & -2.9 & -2.8 & 1.8 & 39 & -61 & -23 & -77 \\
1994 & 2.5 & 0 & 3.6 & 3.6 & 1.8 & 0.7 & 28 & 72 & 0 & 100 \\
1995 & 1.7 & 0.4 & 0 & -0.4 & 0.2 & 1.5 & 88 & 12 & 100 & 0 \\
1996 & 0.8 & 0 & -0.5 & -0.5 & -0.3 & 1.1 & 81 & -19 & 0 & -100 \\
1997 & 1.8 & -0.1 & 0.8 & 0.9 & 0.3 & 1.4 & 80 & 20 & -11 & 89 \\
1998 & 2 & 1.2 & 3.9 & 2.7 & 2.5 & -0.5 & -17 & 83 & 24 & 76 \\
1999 & 2 & 1.6 & 4.6 & 3.0 & 3.1 & -1.1 & -26 & 74 & 26 & 74 \\
2000 & 3 & 2.3 & 2.3 & 0.0 & 2.3 & 0.7 & 23 & 77 & 50 & 50
\end{tabular}




\begin{tabular}{ccccccccccc}
2001 & 1.7 & -0.3 & -2.5 & -2.2 & -1.4 & 3.2 & 69 & -31 & -11 & 89 \\
2002 & 0 & -0.4 & -5.8 & -5.4 & -3.1 & 3.2 & 50 & -50 & -6 & -94 \\
2003 & -0.7 & -1.1 & -1.3 & -0.2 & -1.2 & 0.5 & 29 & -71 & -46 & -54 \\
2004 & 1.2 & 0.3 & 0 & -0.3 & 0.1 & 1.0 & 87 & 13 & 100 & 0 \\
2005 & 0.7 & 0 & 0.7 & 0.7 & 0.3 & 0.3 & 50 & 50 & 0 & 100 \\
2006 & 3.7 & 0.8 & 7.5 & 6.6 & 4.1 & -0.4 & -9 & 91 & 10 & 90 \\
2007 & 3.3 & 1.7 & 4.1 & 2.4 & 2.9 & 0.4 & 12 & 88 & 30 & 70 \\
2008 & 1.1 & 1.3 & 1.5 & 0.2 & 1.4 & -0.3 & -18 & 82 & 46 & 54 \\
2009 & -5.6 & 0.1 & -10.1 & -10.2 & -5.1 & -0.5 & -8 & -92 & 1 & -99 \\
2010 & 4.1 & 0.3 & 5.4 & 5.1 & 2.8 & 1.2 & 31 & 69 & 5 & 95 \\
2011 & 3.7 & 1.4 & 7.2 & 5.7 & 4.3 & -0.5 & -11 & 89 & 17 & 83 \\
2012 & 0.4 & 1.2 & -0.4 & -1.6 & 0.4 & 0.0 & 1 & 99 & 75 & -25 \\
2013 & 0.3 & 0.6 & -1.3 & -1.9 & -0.4 & 0.7 & 65 & -35 & 31 & -69 \\
2014 & 1.6 & 0.9 & 3.5 & 2.6 & 2.2 & -0.6 & -21 & 79 & 21 & 79 \\
2015 & 1.7 & 0.8 & 2.2 & 1.4 & 1.5 & 0.2 & 12 & 88 & 27 & 73 \\
2016 & 1.6 & 1.1 & 2.5 & 1.4 & 1.8 & -0.2 & -10 & 90 & 31 & 69 \\
2017 & 1.6 & 0.8 & 2.7 & 1.9 & 1.7 & -0.1 & -8 & 92 & 23 & 77 \\
$1991 /$ & 1.47 & 0.55 & 1.25 & 0.7 & 0.9 & 0.6 & 38 & 62 & 31 & 69 \\
2017 & & & & & & & & & & \\
\hline
\end{tabular}

Source: Statistical Annexes of European Economy, AMNECO database; own calculations.

Table 4. The values of dynamic intensity and extensity parameters and dynamic parameters of the share of the influence of the labor or capital development on the development of TIF for the Czech Republic

\begin{tabular}{ccccccccccc}
\hline year & G(Y) & $\mathbf{G}(\mathbf{L})$ & $\mathbf{G}(\mathbf{K})$ & $\mathbf{G}(\mathbf{K} / \mathbf{L})$ & $\mathbf{G}(\mathbf{T I F})$ & $\mathbf{G}(\mathbf{T F P})$ & $\mathbf{i}$ & $\mathbf{e}$ & $\mathbf{l}$ & $\mathbf{k}$ \\
\hline 1991 & $-11 . .6$ & -5.5 & -27.3 & -23.1 & -17.1 & 6.6 & 26 & -74 & -15 & -85 \\
1992 & -0.5 & -2.6 & 16.5 & 19.6 & 6.5 & -6.6 & -52 & 48 & -15 & 85 \\
1993 & 0.1 & -1.6 & 0.2 & 1.8 & -0.7 & 0.8 & 53 & -47 & -89 & 11 \\
1994 & 2.9 & 1.1 & 11.7 & 10.5 & 6.3 & -3.2 & -35 & 65 & 9 & 91 \\
1995 & 6.2 & 0.7 & 23.3 & 22.4 & 11.4 & -4.7 & -31 & 69 & 3 & 97 \\
1996 & 4.3 & 0.5 & 9.8 & 9.3 & 5.0 & -0.7 & -13 & 87 & 5 & 95 \\
1997 & -0.7 & -0.7 & -5.2 & -4.5 & -3.0 & 2.3 & 43 & -57 & -12 & -88 \\
1998 & -0.3 & -1.7 & -1.1 & 0.6 & -1.4 & 1.1 & 44 & -56 & -61 & -39 \\
1999 & 1.4 & -2.2 & -2.6 & -0.4 & -2.4 & 3.9 & 61 & -39 & -46 & -54 \\
2000 & 4.3 & -0.8 & 8.4 & 9.3 & 3.7 & 0.6 & 14 & 86 & -9 & 91 \\
2001 & 3.1 & -0.3 & 5.6 & 5.9 & 2.6 & 0.5 & 16 & 84 & -5 & 95 \\
2002 & 1.6 & 0.6 & 2.2 & 1.6 & 1.4 & 0.2 & 13 & 87 & 22 & 78 \\
2003 & 3.6 & -0.8 & 1.8 & 2.6 & 0.5 & 3.1 & 86 & 14 & -31 & 69 \\
2004 & 4.9 & -0.2 & 3.9 & 4.1 & 1.8 & 3.0 & 62 & 38 & -5 & 95 \\
2005 & 6.4 & 1.9 & 6.4 & 4.4 & 4.1 & 2.2 & 35 & 65 & 23 & 77 \\
2006 & 6.9 & 1.3 & 5.9 & 4.5 & 3.6 & 3.2 & 47 & 53 & 18 & 82 \\
2007 & 5.5 & 2.1 & 13.5 & 11.2 & 7.6 & -2.0 & -21 & 79 & 14 & 86 \\
2008 & 2.7 & 2.2 & 2.5 & 0.3 & 2.3 & 0.3 & 13 & 87 & 47 & 53 \\
2009 & -4.8 & -1.8 & -10.1 & -8.5 & -6.0 & 1.3 & 17 & -83 & -15 & -85
\end{tabular}




\begin{tabular}{ccccccccccc}
2010 & 2.3 & -1.0 & 1.3 & 2.3 & 0.1 & 2.2 & 94 & 6 & -44 & 56 \\
2011 & 2.0 & -0.3 & 1.1 & 1.4 & 0.4 & 1.6 & 80 & 20 & -22 & 78 \\
2012 & -0.9 & 0.4 & -3.2 & -3.6 & -1.4 & 0.5 & 27 & -73 & 11 & -89 \\
2013 & -0.5 & 0.3 & -2.7 & -3.0 & -1.2 & 0.7 & 37 & -63 & 10 & -90 \\
2014 & 2 & 0.6 & 2 & 1.4 & 1.3 & 0.7 & 35 & 65 & 23 & 77 \\
2015 & 4.2 & 1.2 & 7.3 & 6.0 & 4.2 & 0.0 & 0 & 100 & 14 & 86 \\
2016 & 2.1 & 0.4 & -0.5 & 0.9 & -0.1 & 2.2 & 98 & -2 & 44 & -56 \\
2017 & 2.6 & 0.3 & 3.0 & 2.7 & 1.6 & 0.9 & 37 & 63 & 9 & 91 \\
$1991 / 2017$ & 1.77 & -0.23 & 2.30 & 2.5 & 1.0 & 0.7 & 42 & 58 & -9 & 91 \\
\hline
\end{tabular}

Source: Statistical Annexes of European Economy, AMNECO database; own calculations

The very similar economic development in Germany and the Czech Republic (CR) is clear from Figure 1 describing GDP development in both countries at constant 2010 prices. This similarity is due to numerous interrelations between the two economies, which also has historical roots. Deviations are more essential in the 1990s, when the CR was going through economic transformations including economic crisis at the second half of the period and Germany had to solve the consequences of the reunification in 1990. The Czech Republic has higher growth rate period after the year 2000 as the consequence of its preparation on EU membership. The EU entrance was connected with capital inflow that brought to the country new modern technology. It also meant higher international involvement and cooperation, higher international division of labor and other positive factors. The result was quit high Czech growth rate and high positive yearly values of dynamic intensity parameter. Both countries were hit by the deep crisis in 2009. The recovery from the crisis after 2009 also happens similarly.

As shown in the last lines of Tables 1 and 2, the Czech Republic achieved an only slightly higher average GDP growth rate for the whole period, i.e. 1.77\% compared to $1.47 \%$ for Germany. The biggest difference is in the labor factor, which in the Czech Republic is declining on average by a quarter of a percent year-on-year, while in Germany it is growing by half a percent. Intensity and extensity are also very similar, since in both cases there is predominantly extensive development, however with high intensity. The intensity in the Czech Republic is 4 percentage points higher, reaching $42 \%$, while in Germany it is $38 \%$. The balance up to $100 \%$ in both countries is extensive development.

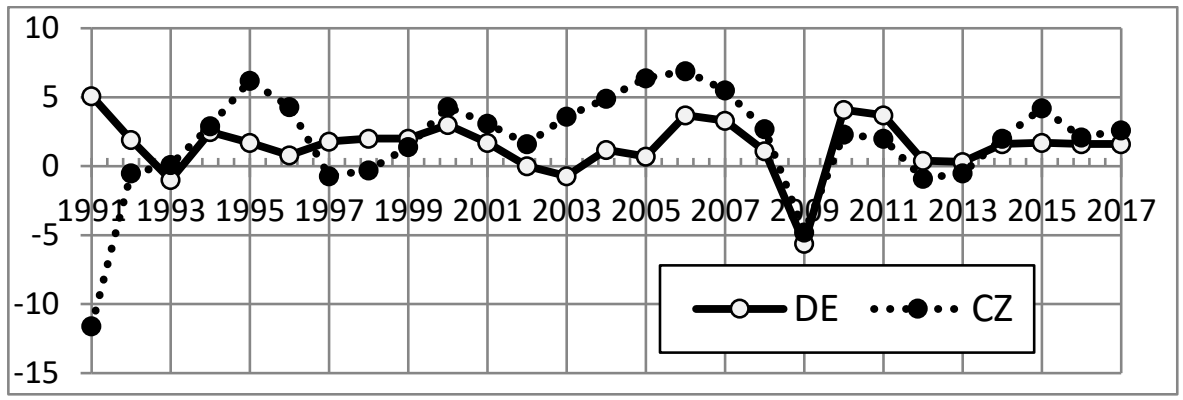

Fig. 1. GDP development for the period 1991 to 2017 for Germany (DE) and the Czech Republic (CZ) 
If we concentrate on the columns $i$ and $e$ in the tables 3 and 4 , it is possible to see the year-on-year development in intensity and extensity is similar in both countries, especially after the period of transformation in the 1990s. The processes of transformation of the Czech economy and the impacts of German unification were nevertheless different in nature. Former East Germany can rely on wealthy West Germany that can easily export to East Germany its technology, knowledge and other factors. People form East Germany could further move to west and to find here jobs that was connected with higher level of capital goods that increased their productivity. All these factors caused mainly positive values of dynamic intensity parameter $(i)$. The position of Czech Republic was more difficult. Czech economic transformation meant deeper changes resulting in negative values of dynamic intensity parameter in the beginning of the transformation. Negative German values of dynamic intensity parameters in years 1998 and 1999 were mainly due to the entry of Germany into the euro area. Entry into the euro area is a process in which we can expect negative extensity.

The period 2000 - 2007 means positive values of dynamic intensity parameter for both countries in whole period (except year 2006 in the case of Germany and 2007 in the case of the Czech Republic). Germany was able to succeed in liberalization of labor market (so called The Hartz Reform, see e. g. Krebs and Scheffel 2013 for details). It also uses the fact that euro exchange rate is generally under valuated in its case what is favorable for German export. The more intensive development in the CR in the same period can be attributed to the preparation of the CR for accession to the $\mathrm{EU}$ and the impacts of this serious step.

The crisis in year 2009 brought negative values of both parameters in the case of the Czech Republic and negative value of German dynamic extensity parameter. The process of recovery from the crisis are connected with slightly different Czech and German values of both parameter. However, the values of parameters are affected by temporary demand shock and interpretation of their year values can be misleading (see Chapter 3 for details). When we shortly move to the to the analysis of the dynamic parameter of the share of the influence of the labor development on the development of TIF $(l)$ and the dynamic parameter of the share of the influence of the capital development on the development of $T I F(k)$ we find higher differences. They are caused due to different labor mobility (generally higher in Germany), higher change of capital structure that was realized in the Czech Republic and other factors.

\section{Discussion}

How accurate are the parameters? And do they always describe exactly what happens in reality? The values of the parameters depend, of course, on input data. Our approach uses as the input data only growth rates of labor, capital and GDP. The analysis looks at labor and capital as a homogeneous factor and it does not consider other features as education, skill, quality of capital goods and so on. However, identical value of labor or capital change can result in different GDP development. For instance, if one country experiences growth of educated labor force (e. g. people 
with university education) and the second on growth of unskilled person. Although labor growth rates are equal in both countries GDP growth rates differ. Similarly, if one country is introducing modern technically progressive capital goods and the second one increases number of obsolete ones, the change of GDP will be probably different even in the case when both changes of capital are expressed by same value. It is reasonable to expect that the change containing a qualitative character will result in higher TFP change of and thus in higher value of dynamic intensity parameter.

If we want to distinguish quality of inputs, it is possible to add to equation other factors or to divide labor and capital to more specific forms. Equation (3) then can be for instance rewritten as

$$
T I F=\sum_{i=1}^{n} K_{i}^{\alpha} \cdot \sum_{j=1}^{m} L_{j}^{1-\alpha},
$$

where $i$ and $\mathrm{j}$ represents different forms of capital and labor. The equation (5) than can be rewritten as:

$$
I(T I F)=\sum_{i=1}^{n} I(K)_{i}^{\alpha} \cdot \sum_{j=1}^{m} I(L)_{j}^{1-\alpha} .
$$

Share of the influence of the specific factor (e.g. educated labor force) on TIF development can be then expressed as:

$$
\begin{aligned}
k_{i} & =\frac{\alpha \cdot \ln I\left(\backslash \backslash K_{i}\right)}{\alpha \cdot \ln I\left(\sum_{i=1}^{n} K_{i}\right) \mid+(1-\alpha) \cdot \ln I\left(\sum_{j=1}^{m} L_{j}\right) !}, \\
i_{j} & =\frac{(1-\alpha) \cdot \ln I\left(L_{j}\right)}{\alpha \cdot \ln I\left(\sum_{i=1}^{n} K_{i}\right) \mid+(1-\alpha) \cdot \ln I\left(\sum_{j=1}^{m} L_{j}\right) !} .
\end{aligned}
$$

The interpretation of dynamic intensity or extensity parameters' values can be sometimes misleading. Especially in the case of sudden demand or supply shocks. Yearly values of both parameters are usually affected by a shock. For instance, the output in the case of negative demand shock decreases, but amount of inputs usually does not decrease in the same rate. The input decline is usually lower, or inputs can even stagnate or grow especially in the beginning of the shock when their development is not affected by the shock. The dynamic parameter of intensity is negative in such case. But the country does not experience real technological regression. It is reasonable for firms not to reduce amount of inputs in same rate as output decline. If the negative shock is temporary, it makes sense to keep the inputs in the firms and to avoid costs connected with input reduction and subsequent input increase. Oppositely, when the demand shock ends, inputs and output usually grow but the inputs change is lower that the output change. The value of dynamic intensity parameter is positive, but it does not mean real technological progress. Firms only started to use more the inputs that had not been reduced during shock.

Negative supply shock due to sudden increase prices of inputs (e. g. oil) can cause misinterpretation too. The change of inputs is usually higher than change of output due to the shock. Value of inputs usually grows; value of output grows smaller, stagnates or even declines. The result is negative value of dynamic intensity parameter which, however, does not again mean technological regression. Economy is not only able to respond in short run to the shock appropriately. Generally, yearly 
values of dynamic intensity and extensity parameters express what happens on the aggregate level. Their negative values can be seen as a sign of some economic problems, but the essence of the problem must be further investigated. It is not possible to conclude without other research that yearly negative values mean real technological regression or real decline of inputs. Yearly negative value of dynamic extensive parameters can be further caused by change of depreciation methodology or by the fact the new capital good cost less than the removed ones.

Extraordinary yearly positive values of both parameters must be carefully analyzed too as they often describe the situation when an economy improves from previous negative development. The positive values thus balance what happened in the past. The value of the parameters can be also misleading in the case when all values (I(TIF), I(TFP) I(Y)) are close to 1 - so they describe slight change. The small difference in their values in such situation can cause extraordinary value of any dynamic parameter - e.g. value of $i$ is $98 \%$ and value of $e$ is $2 \%$. A big technological change seems to happen, but it does not. Long run values of both parameters counted e. g. for 10-years period describe technological progress or regression more preciously. Long run development is not affected by temporary shocks, it contains higher aggregate values of $\mathrm{I}(T I F), I(T F P)$ and $I(Y)$ and it is possible to analyze whether GDP development is really based on intensive or extensive factors

\section{Conclusion}

The methodology for measuring the quality of the development of the economic trajectory based on the dynamic intensity and extensity parameters and dynamic parameters of the share of the influence of the labor or capital development on the development TIF differs from existing methods using at the national economy level, primarily through growth accounting, because it is based not on additive relations between component factors, but multiplicative relations of the Cobb-Douglas production function type. The paper introduces the parameters and it provides explanation of the consequences of their choice. We further discuss the issue of capital and labor weights and explain why it is possible to set them equal 0.5 .

The German and Czech example shows that the parameters give meaningful results that clearly depict the key events in the development of both countries. The values of parameters confirm similar economic development and the dependence of Czech economy on Germany. Larger differences are apparent in all the monitored characteristics in the 1990s, which were a period of fundamental transformation in the Czech Republic, while Germany was dealing with the consequences of unification. The beginning of the millennium in Germany was mainly influenced by its entry into the euro area, while the CR subsequently acceded to the EU. The pre-crisis period and the recovery from the crisis were very similar in both countries. The slightly higher intensity in the Czech Republic for whole period 1991 - 2017 comes mainly from the convergence process. 
Acknowledgements. The paper was created during solution the student project “Zdokonalení penzijního systému jako intenzifikační faktor ekonomiky“that use purpose-built support for Specific university research of University of Finance and Administration.

\section{References}

1. Barro, R.: Notes on Growth Accounting. Journal of Economic Growth, 4(2), 119-137 (1999).

2. Cyhelský, L., Mihola, J., Wawrosz, P.: Quality Indicators of Economic Development at All Level of the Economy. Statistika (Statistics and Economy Journal), 49(2), 29-43 (2012).

3. Beckerman, W., \& Denison, E.: The Sources of Economic Growth in the United States and the Alternatives Before Us. The Economic Journal, 72(288), 935 (1962), http://dx.doi.org/10.2307/2228363.

4. Hájek, M., Mihola, J.: Analýza vlivu souhrnné produktivity faktorů na ekonomický růst České republiky. Politická ekonomie, 57(6), 740-753 (2009)

5. la Grandville, O.: Economic Growth: A Unified Approach. Cambridge University Press, Cambridge (UK) (2016).

6. Froeb, L. M., Ward, M. R: Managerial Economics. $4^{\text {th }}$ edition. Cengage Learning, London (2015).

7. Jorgeson, D. V., Griliches, Z.: The explanation of productivity changes. Review of Economic Studies, 49, 249-280 (1967).

8. Krebs, T., Scheffel, M.: Macroeconomic Evaluation of Labor Market Reform in Germany. IMF Economic Review; 61(4), 664-701 (2013).

9. Mihola, J.: Agregátní produkční funkce a podíl vlivu intenzivních faktorů. Statistika, 44(2), 108-132 (2007a).

10. Mihola, J.: Souhrnná produktivita faktorů - přímý výpočet. Statistika, 44(6), 446-463 (2007).

11. Mihola, J., Wawrosz, P.: Development Intensity of four Prominent Economies. Statistika (Statistics and Economy Journal), 93(3), 26-40 (2013.)

12. Mihola, J., Wawrosz, P.: Analysis of Long-Run GDP Development in the USA, the EU15, China and the USSR/Russia. Statistika (Statistics and Economy Journal), 94(4), 15-28 (2014).

13. Mihola, J., Wawrosz, P.: Alternativní metoda měření extenzivních a intenzivních faktorů změny HDP a její aplikace na HDP USA a Číny. Politická ekonomie, 62(5), 583-604 (2014).

14. Mihola, J., Wawrosz, P.: Analýza vývoje intenzity hrubého domácího produktu České republiky a Slovenské republiky. Ekonomický časopis, 63(8), 775-795 (2015).

15. Sandamo, A.: Economic evolving. Princeton University Press, Princeton (2011).

16. Solow, R. M.: Technical Change and the Aggregate Production Function. Review of Economics and Statistics, 39(3), 312-320 (1957). 